\title{
Growth and Survival Variation among Scots Pine (Pinus sylvestris L.) Provenances
}

\author{
Süleyman Gülcüi and Nebi Bilir \\ Forestry Faculty, Suleyman Demirel University, 32260 Isparta, Turkey \\ Correspondence should be addressed to Nebi Bilir; nebibilir@sdu.edu.tr
}

Received 5 August 2016; Revised 10 October 2016; Accepted 4 December 2016; Published 4 January 2017

Academic Editor: Muzaffar Hussain

Copyright (C) 2017 S. Gülcü and N. Bilir. This is an open access article distributed under the Creative Commons Attribution License, which permits unrestricted use, distribution, and reproduction in any medium, provided the original work is properly cited.

\begin{abstract}
Tree height, basal diameter, and survival were examined in thirteen-year-old provenance test established by 30 seed sources of Scots pine (Pinus sylvestris L.) at two exotic sites of the species in Southern part of Turkey. Variations within provenance and among provenances and relations among the traits were estimated to compare Scots pine provenance and two other native species. Averages of tree height and basal diameter were $350 \mathrm{~cm}$ and $52.7 \mathrm{~mm}$ in Aydogmus site and $385 \mathrm{~cm}$ and $51.2 \mathrm{~mm}$ in Kemer site, respectively. There were large differences within and among provenances for the characters. Sites were similar $(p>0.05)$ for the characters, while there were significant differences ( $p \leq 0.05$ ) among provenances within site according to results of variance analysis (ANOVA). Scots pine provenances were higher and had more thickness than that of black pine (Pinus nigra Arnold) and Taurus cedar (Cedrus libani A. Rich.) which were natural species of the region. There were positive and significant $(p<0.05)$ correlations between height and basal diameter in the species. Average survivals were $56 \%$ and $35 \%$ of the provenances in the sites. They were $71 \%$ and $11 \%$ in black pine and $53 \%$ in Taurus cedar for the sites respectively.
\end{abstract}

\section{Introduction}

Scots pine (Pinus sylvestris) is classified as one of the economically important tree species for Turkish forestry in the "National Tree Breeding and Seed Production Programme" [1]. The species grows between 0 and 2700 meters above sea level in Turkey. Pure and mixed stands of the species occupy roughly 750000 ha in Turkey, of which roughly 475000 ha are considered to be productive forests (Figure 1).

Scots pine is one of the valuable commercial forest tree species in Europe and Asia. Besides, it is interesting as an introduced exotic species in Korea, China, Mexico, and New Zealand, where provenance and cultivation trials have been established [2]. Within its wide natural and artificial range in the Euroasiatic continent the species shows large variability of its adaptation and growth features [3]. Provenance trials with forest trees provide valuable information about growth and adaptability of populations often transferred over large geographical and climatic distances [3]. Estimation of provenance variation is also one of the main stages of tree breeding programme, to establish successful plantations and to determine seed transfer regions. Provenance tests with Scots pine date back to as early as the 19th century.
Few of those tests would meet the present-day statistical standards required for field experimentation, but frequently the progeny of one stand (provenance) was planted at several experimental sites. Most of those early experiments were limited to the scale of national tests [3]. While many national and international studies were conducted on provenance test for different purposes in the species in many countries (e.g., [4-11]) or different forest tree species (e.g., [12-15]), the present study is one of the first investigations in Southern Turkey which is exotic for the species.

The purposes of this study were to estimate variations of tree height and basal diameter within provenance and among provenances, to compare Scots pine to native black pine (Pinus nigra) and Taurus cedar (Cedrus libani) species of the sites, and to evaluate relations between height and diameter in the species to estimate better provenance/s for the region.

\section{Materials and Methods}

This study was carried out in two experimental areas (latitude $38^{\circ} 36^{\prime} \mathrm{N}$, longitude $30^{\circ} 24^{\prime} \mathrm{E}$, and altitude $1100 \mathrm{~m}$ asl. called 


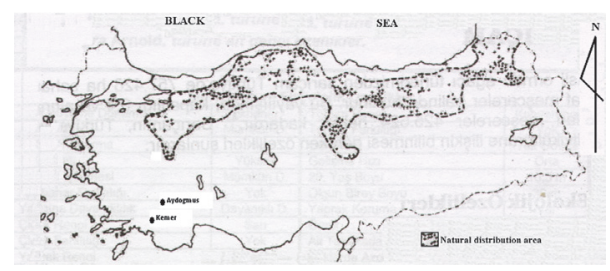

FIgURE 1: Natural distribution area of Scots pine in Turkey, and experimental sites.

Aydogmus site; latitude $37^{\circ} 35^{\prime} \mathrm{N}$, longitude $30^{\circ} 06^{\prime} \mathrm{E}$, and altitude $1180 \mathrm{~m}$ asl. called Kemer site in the paper) in Southern Turkey, established by 30 Scotch pine provenances and native Taurus cedar and Anatolian black pine provenances for comparison (Table 1).

The experiments were established as "Randomized Blocks" with three blocks and $2.5 \times 2 \mathrm{~m}$ spacing in year 2000. Each provenance was represented by thirty-two-yearold containerized seedlings in each replication/block. Data of survival, tree height $(H, \mathrm{~cm})$, and basal diameter $\left(D_{0}, \mathrm{~mm}\right)$, also called base diameter at soil surface, were collected at thirteen-year-old provenance test in October of 2013. Tree height and basal diameter were measured by Haglöf-Vertex hypsometer and electronic caliper, respectively.

The statistical analysis was carried out by SPSS statistical package according to the following model of ANOVA used for the analysis:

$$
Y_{i j k m}=\mu+S_{i}+B_{j(i)}+P_{k}+S P_{i k}+B P_{j(i) k}+e_{i j k m}
$$

where $Y_{i j k}$ is the observation from the $m$ th tree of $k$ th provenance at $j$ th block of $i$ th site, $\mu$ is overall mean, $S_{i}$ is the effect of the $i$ th site, $B_{j(i)}$ is the effect of $j$ th block at $i$ th site, $P_{k}$ is effect of $k$ th provenance, $S P_{i k}$ is the interaction between $k$ th provenance and $i$ th site, $B P_{j(i) k}$ is interaction between $k$ th provenance and $j$ th block at $i$ th site, and $e_{i j k m}$ is random error. Provenances were grouped by Duncan's multiple range test. Individual phenotypic correlations among traits were also calculated.

Correlation between tree height and basal diameter was also calculated by Pearson's correlation using SPSS statistical package program [16].

\section{Results and Discussion}

3.1. Traits. Survival rate, averages, and ranges of the tree height and basal diameter for provenances and sites were given in Table 2.

Survival was one of the most important criterions in economical and biological success of plantation forestry. It was gaining importance based on climate change by provenance test. It was emphasized that provenance trials series with many test localities covering a large variation of climatic conditions were ideal for estimates of the consequences of changes of temperature climate [9]. Survival rates were changed for species, sites, and provenances (Table 2). They were $56 \%$ (varied between $31 \%$ and $76 \%$ ) and $35 \%$ (18\% and $53 \%)$ in experimental sites. While the survival was lowest
TABLE 1: Geographic details of the provenances.

\begin{tabular}{|c|c|c|c|c|}
\hline $\begin{array}{l}\text { Provenance } \\
\text { number }\end{array}$ & Country & $\begin{array}{l}\text { Latitude } \\
(\mathrm{N})\end{array}$ & $\begin{array}{l}\text { Longitude } \\
\text { (E) }\end{array}$ & $\begin{array}{l}\text { Altitude } \\
\text { (m) }\end{array}$ \\
\hline 1 & Turkey & $40^{\circ} 53^{\prime}$ & 3220 & 1550 \\
\hline 2 & Turkey & $40^{\circ} 38^{\prime}$ & 4228 & 2050 \\
\hline $3(\mathrm{GR})^{*}$ & Greece & $41^{\circ} 17^{\prime}$ & Unknown & 1600 \\
\hline 4 & Turkey & $41^{\circ} 10^{\prime}$ & 3505 & 1200 \\
\hline 5 & Turkey & $40^{\circ} 31^{\prime}$ & 3208 & 1550 \\
\hline $6^{* *}$ & Turkey & $39^{\circ} 58^{\prime}$ & 3107 & 1550 \\
\hline $7^{* *}$ & Turkey & $40^{\circ} 32^{\prime}$ & 3209 & 1575 \\
\hline 8 & Turkey & $41^{\circ} 22^{\prime}$ & 3320 & 1250 \\
\hline 9 & Turkey & $40^{\circ} 15^{\prime}$ & 4240 & 2300 \\
\hline $10^{* *}$ & Turkey & $39^{\circ} 41^{\prime}$ & 3550 & 910 \\
\hline $11^{* *}$ & Turkey & $39^{\circ} 51^{\prime}$ & 3106 & 1320 \\
\hline 12 & Turkey & $38^{\circ} 54^{\prime}$ & 3110 & 1675 \\
\hline 13 & Turkey & $39^{\circ} 34^{\prime}$ & 3552 & 1750 \\
\hline 14 & Turkey & $40^{\circ} 45^{\prime}$ & 4233 & 2250 \\
\hline 15 & Turkey & $41^{\circ} 34^{\prime}$ & 3122 & 1300 \\
\hline 16 & Turkey & $40^{\circ} 23^{\prime}$ & 3755 & 1950 \\
\hline 17 & Turkey & $40^{\circ} 37^{\prime}$ & 3139 & 1350 \\
\hline 18 & Turkey & $41^{\circ} 01^{\prime}$ & 3421 & 1600 \\
\hline 19 & Turkey & $39^{\circ} 58^{\prime}$ & 3109 & 1550 \\
\hline 20 & Turkey & $41^{\circ} 10^{\prime}$ & 3503 & 1300 \\
\hline 21 & Turkey & $40^{\circ} 22^{\prime}$ & 3752 & 1650 \\
\hline 22 & Turkey & $41^{\circ} 02^{\prime}$ & 3337 & 1500 \\
\hline 23 & Turkey & $39^{\circ} 34^{\prime}$ & 3260 & 1800 \\
\hline 24 (GR) & Greece & Unknown & Unknown & Unknown \\
\hline 25 & Turkey & $40^{\circ} 18^{\prime}$ & 4237 & 2350 \\
\hline 26 & Turkey & $40^{\circ} 26^{\prime}$ & 4235 & 2250 \\
\hline 27 & Turkey & $40^{\circ} 37^{\prime}$ & 3050 & 1450 \\
\hline $28^{* *}$ & Turkey & $39^{\circ} 45^{\prime}$ & 3110 & 1350 \\
\hline 29 (FR) & France & $45^{\circ} 18^{\prime}$ & Unknown & 860 \\
\hline $30^{* *}$ & Turkey & $39^{\circ} 54^{\prime}$ & 4118 & 1570 \\
\hline P. nigra & Turkey & $37^{\circ} 29^{\prime}$ & 3043 & 1000 \\
\hline C. libani & Turkey & $37^{\circ} 44^{\prime}$ & 3052 & 1567 \\
\hline
\end{tabular}

${ }^{*}$ GR: Greece; FR: France. ${ }^{* *}$ Seed orchards.

(53\%) for Taurus cedar in first site, it was the highest (53\%) for the species in second site. There was no any higher survival provenance of Scots pine than Taurus cedar in second site (Table 2 and Figure 2). Pinus sylvestris provenances showed better survival performance than that of $P$. contorta in Sweden [10]. Average survival was reported to be $44.5 \%$ with overall Scots pine provenance trials ranging from 5 to 17 years in Poland [17]. It was $41.5 \%$ in 30 th year results of provenance trials in the species [3]. Large differences among provenances for survival were also reported in provenance trials of Scots pine in different countries $[3,11,18,19]$. Significant relationship between survival and population/origin was found in provenance trials of Scots pine [20]. It was known that there could be many environmental and genetic effects on survival. The results showed importance of provenance trials 


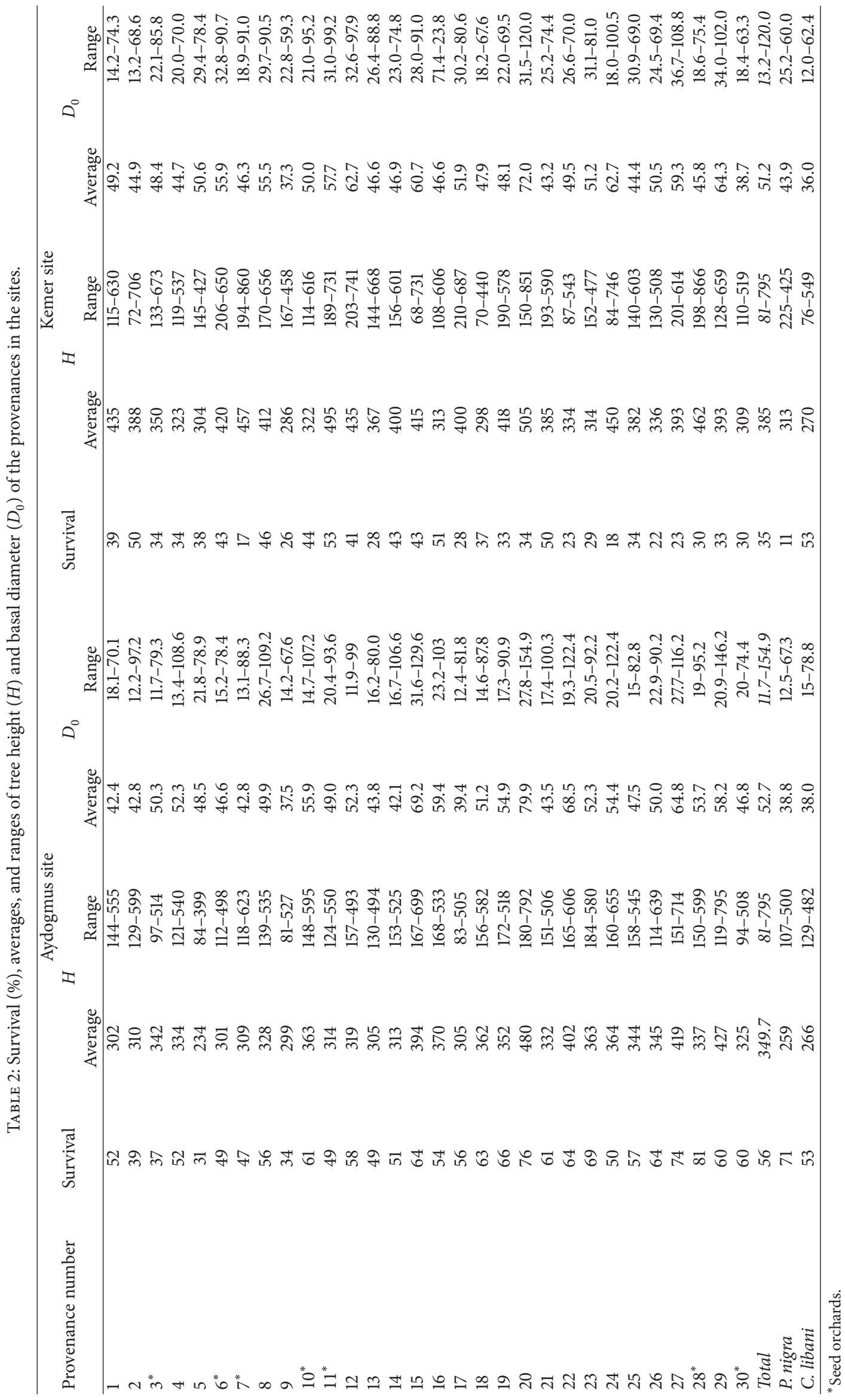




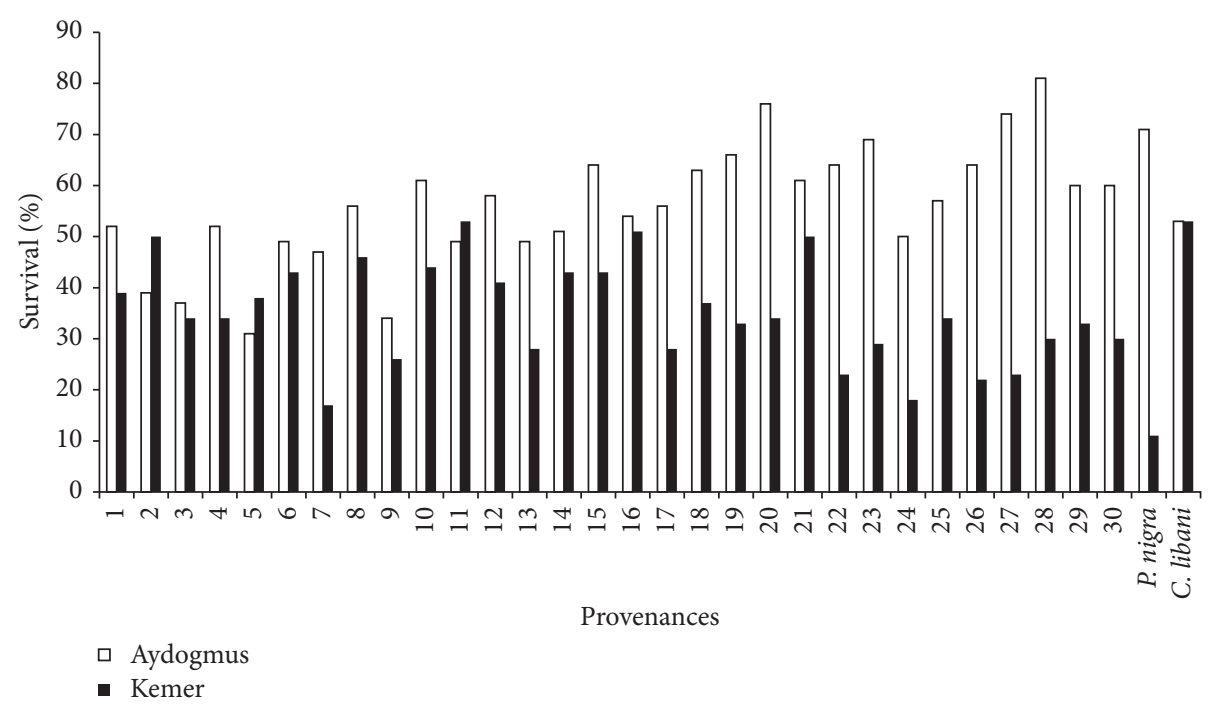

FIGURE 2: Survival of provenances for site.

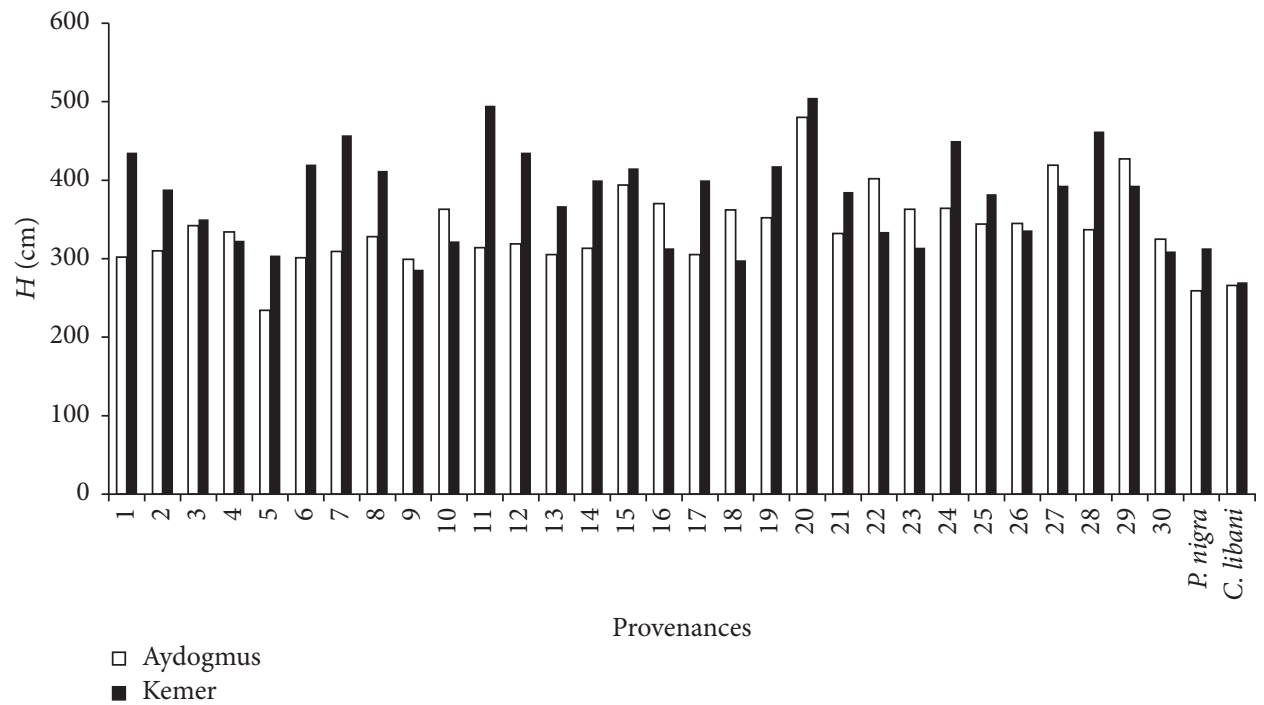

FIGURE 3: Tree height of provenances for site.

for selection of regional seed sources in plantation forestry. In German Scots pine provenance trial results of Taeger et al. [21] highlight the importance of genotype $\times$ environment interaction in response to extreme climatic events, which have to be considered in the interpretation of population adaptation to climate change. In Polish provenance trials, results of Barzdajn et al. [3] showed that the southern populations that moved so far north suffered too much of a climatic transfer. On the other hand, good survival of northern populations in a milder environment of our research site, as compared to their native climate, indicates that there was some potential within those populations to adapt to changes in climate corresponding to that transfer.

Averages of tree height and basal diameter were $350 \mathrm{~cm}$ and $385 \mathrm{~cm}$ and $52.7 \mathrm{~mm}$ and $51.2 \mathrm{~mm}$ in the sites, respectively (Table 2). As seen from Table 2, there were large differences within provenance and among provenances for tree height and basal diameter. The result was well in accordance with the early results from the species $[3,11,19,22,23]$. These results indicated that there was a large variation among tested populations in growth at the examined test site and within species. However, while there were $15-20 \%$ differences for height and radial growth among provenances of Norway spruce, qualitative traits such as stem shape, branch density, and shape and health state were similar in the species [12] and had statistically significant difference $(0.05>p)$ among populations of black pine reported by Gülcü et al. [24] for growth characters. Scots pine provenances showed higher height and diameter performances than that of black pine and Taurus cedar which were natural forest tree species of the sites (Figures 3 and 4) opposite to primary results of the trial [25]. However, growth performances could chance for the provenances in the future as also emphasized in Polish 


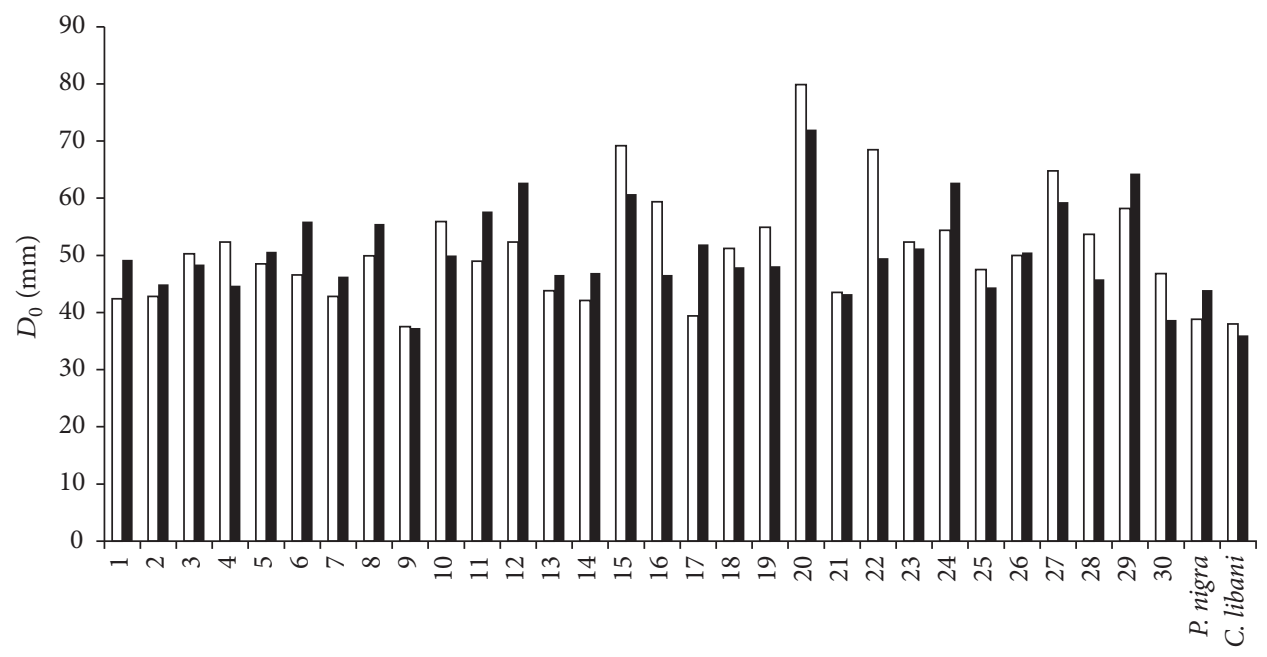

Provenances

$$
\begin{aligned}
& \square \text { Aydogmus } \\
& \square \text { Kemer }
\end{aligned}
$$

FIgURE 4: Basal diameter of provenances for site.

\begin{tabular}{|c|c|c|c|c|}
\hline \multirow{2}{*}{$\begin{array}{l}\text { Source of } \\
\text { variation }^{*}\end{array}$} & \multicolumn{2}{|c|}{$\mathrm{H}$} & \multicolumn{2}{|c|}{$\mathrm{D}_{0}$} \\
\hline & $F$ value & $p$ value $^{* *}$ & $F$ value & $p$ value \\
\hline$S_{i}$ & 56.070 & $p>0.05^{\mathrm{ns}}$ & 0.007 & $p>0.05^{\mathrm{ns}}$ \\
\hline$B_{j}$ & 16.877 & $p>0.05^{\mathrm{ns}}$ & 59.829 & $p>0.05^{\mathrm{ns}}$ \\
\hline$P_{k}$ & 8.454 & $0.05>p$ & 13.034 & $0.05>p$ \\
\hline$S P_{i k}$ & 7.637 & $0.05>p$ & 4.034 & $0.05>p$ \\
\hline$B P_{j(i) k}$ & 2.879 & $0.05>p$ & 2.928 & $0.05>p$ \\
\hline
\end{tabular}

TABLE 3: Results of analysis of variance for the characters.

${ }^{*} S_{i}$ is the effect of the $i$ th site, $B_{j(i)}$ is the effect of $j$ th block at $i$ th site, $P_{k}$ is the effect of $k$ th provenance, $S P_{i k}$ is the interaction between $k$ th provenance and $i$ th site, and $B P_{j(i) k}$ is the interaction between $k$ th provenance and $j$ th block at $i$ th site; ${ }^{\text {ns }}$ difference is not statistically significant.

provenance trials of Scots pine by Barzdajn et al. [3] and other trials $[25,26]$.

Averages of tree height and basal diameter of seed stand provenances were generally higher than that of seed orchard provenances marked in Table 1 . This was not an expected situation. However, seed orchards have been established with clones or seedlings, collected from plus trees selected phenotypically from natural seed stands. Besides, it could be said that provenances of the present study had higher height and diameter than early studies [4-6].

Sites were similar for tree height and basal diameter $(p>0.05)$, while there were significant differences $(p \leq$ $0.05)$ among provenances according to results of analysis of variance (ANOVA) (Table 3) and Duncan's multiple range test (Table 4$)$. However, site $\times$ provenance interaction was significant $(p<0.05)$. The result was well in accordance with the early results from provenance trials of the species $[3,19]$. Ulbrichová et al. [12] reported that environmental variables were significantly effective on growth characters in provenance test of Norway spruce. Significant site $\times$ provenance interaction was reported in a provenance test of Eucalyptus robusta [15]. The interaction result of the present study showed large variation for selection capacity and adaptation ability to different site of the species.

3.2. Correlations among the Traits. Positive and significant $(p \leq 0.05)$ correlations were found between tree height and basal diameter in Scots pine $(r=0.643)$, in black pine $(r=0.405)$, and in Taurus cedar $(r=0.634)$. Positive and significant correlation was reported between height and growth traits in Scots pine populations $[3,5,11]$ and between tree height and branch diameter in black pine populations [24] and also Eucalyptus urophylla provenances [14]. The relationship could be used in the future studies on the species.

\section{Conclusions}

In this paper, we reported significant variation in the growth traits and survival among 30 Scots pine provenances and two other native species based on thirteen-year-old provenance trials in Southern Turkey. The variation among provenances and within provenance emphasized importance of mass and individual selection and large adaptation ability of the species. There were positive and significant correlations between growth traits. The relationship could be used in forestry practices of the species such as pruning. The phenotypic selection based on growth traits should be combined by genotypic selection in the future studies.

Scots pine provenances were higher and had more thickness than that of black pine and Taurus cedar. It showed that the Scots pine could be used at low ratio (less than 10\%) in mixed plantation at the region. Therefore, it was needed to collect more data to draw accurate suggestion for better provenance for the region. 
TABLE 4: Homogenous groups of Duncan's multiple range tests.

\begin{tabular}{|c|c|c|c|}
\hline \multicolumn{2}{|c|}{$H$} & \multicolumn{2}{|c|}{$D_{0}$} \\
\hline $\begin{array}{l}\text { Provenance } \\
\text { number }\end{array}$ & $\begin{array}{l}\text { Homogenous } \\
\text { groups* }\end{array}$ & $\begin{array}{c}\text { Provenance } \\
\text { number }\end{array}$ & $\begin{array}{c}\text { Homogenous } \\
\text { groups }\end{array}$ \\
\hline P. nigra & $\mathrm{a}$ & C. libani & $\mathrm{a}$ \\
\hline C. libani & $\mathrm{a}$ & 9 & $\mathrm{a}$ \\
\hline 5 & $\mathrm{a}$ & P. nigra & $a b$ \\
\hline 9 & $\mathrm{ab}$ & 21 & $\mathrm{bc}$ \\
\hline 30 & $\mathrm{bc}$ & 17 & bcd \\
\hline 13 & $\mathrm{~cd}$ & 7 & bcd \\
\hline 4 & cde & 2 & bcde \\
\hline 17 & cdef & 30 & bcdef \\
\hline 18 & cdef & 14 & bcdef \\
\hline 16 & cdef & 13 & bcdef \\
\hline 26 & cdefg & 1 & bcdef \\
\hline 3 & cdefgh & 25 & bcdefgh \\
\hline 10 & cdefgh & 4 & cdefh \\
\hline 7 & cdefgh & 3 & cdefghi \\
\hline 23 & cdefgh & 5 & cdefghi \\
\hline 14 & cdefgh & 18 & cdefghi \\
\hline 2 & cdefgh & 26 & defghi \\
\hline 21 & cdefgh & 6 & cdefghi \\
\hline 6 & cdefgh & 28 & fghi \\
\hline 25 & cdefgh & 16 & hij \\
\hline 1 & defgh & 23 & hij \\
\hline 8 & defghi & 8 & ij \\
\hline 12 & efghi & 19 & ij \\
\hline 28 & fghi & 10 & ij \\
\hline 19 & ghij & 11 & ij \\
\hline 22 & ghijk & 24 & $\mathrm{jk}$ \\
\hline 24 & hijk & 12 & $\mathrm{jk}$ \\
\hline 15 & $\mathrm{ijk}$ & 29 & $\mathrm{kl}$ \\
\hline 11 & $\mathrm{jk}$ & 22 & 1 \\
\hline 27 & $\mathrm{k}$ & 27 & 1 \\
\hline 29 & $\mathrm{k}$ & 15 & 1 \\
\hline 20 & $\mathrm{k}$ & 20 & $\mathrm{~m}$ \\
\hline
\end{tabular}

${ }^{*}$ The same letters are significantly different $(p>0.05) .{ }^{* *}$ Seed orchards.

\section{Competing Interests}

The authors declare no competing interests.

\section{Acknowledgments}

The authors thank Professor Abdullah Gezer for his valuable comments on the paper and thank Dr. Sultan Celik Uysal for her help during data collection and data analysis.

\section{References}

[1] V. Koski and J. Antola, National Tree Breeding and Seed Production Programme for Turkey 1994-2003, The Research
Directorate of Forest Tree Seeds and Tree Breeding Publishers, Ankara, Turkey, 1993.

[2] A. Boratynski, "Range of natural distribution," in Genetics of Scots Pine, M. Grietchy and C. Mátyás, Eds., Elsevier, 1991.

[3] W. Barzdajn, W. Kowalkowski, and D. J. Chmura, "Variation in growth and survival among European provenances of Pinus sylvestris in a 30-year-old experiment," Dendrobiology, vol. 75, pp. 67-77, 2016.

[4] F. Saatcioglu, "Results of the 25 years' provenance experiment established by using 16 Scotch pine of European and 1 of native provenances in Turkey," Silvae Genetica, vol. 16, pp. 172-177, 1967.

[5] B. R. Stephan and M. Liesebach, "Results of the IUFRO 1982 Scots pine (Pinus sylvestris L.) provenance experiment in Southwestern Germany," Silvae Genetica, vol. 45, no. 5-6, pp. 342-354, 1996.

[6] S. Dagdas, S. Tosun, H. Atasoy, and I. Dasdemir, "The first preliminary results of scotch pine (Pinus sylvestris L.) provenances tests in Turkey," Technical Bulletin 272, 1997.

[7] A. M. Shutyaev and M. Giertych, "Height growth variation in a comprehensive Euroasian provenance experiment of Pinus sylvestris L.," Silvae Genetica, vol. 46, pp. 332-349, 1997.

[8] B. Persson and E. G. Ståhl, "Survival and yield of Pinus sylvestris L. as related to provenance transfer and spacing at high altitudes in northern Sweden," Scandinavian Journal of Forest Research, vol. 5, no. 1-4, pp. 381-395, 1990.

[9] E. G. Ståhl, "Changes in wood and stem properties of Pinus sylvestris caused by provenance transfer," Silva Fennica, vol. 32, no. 2, pp. 163-172, 1998.

[10] T. Ericsson, "Survival of Pinus contorta and Pinus sylvestris in northern Sweden," in Proceedings of the IUFRO WP 2.02.06 Symposium, vol. 11, pp. 326-333, 1993.

[11] S. Gulcu and N. Bilir, "Provenance variations of scots pine (Pinus sylvestris L.) in the Southern part of Turkey," Pakistan Journal of Botany, vol. 47, no. 5, pp. 1883-1893, 2015.

[12] I. Ulbrichová, V. Podrázský, F. Beran et al., "Picea abies provenance test in the Czech Republic after 36 years-central European provenances," Journal of Forest Science, vol. 61, no. 11, pp. 465-477, 2015.

[13] K. Johnsen, H. Creighton, L. Jerre, L. Maier, and A. Chris, "Longleaf pine grown in Virginia: a provenance test," in Proceedings of the 17th Biennial Southern Silvicultural Research Conference. e-Gen, Tech. Rep. SRS-203, p. 3, Asheville, NC, USA, 2015.

[14] G. R. Hodge and W. S. Dvorak, "Provenance variation and within-provenance genetic parameters in Eucalyptus urophylla across 125 test sites in Brazil, Colombia, Mexico, South Africa and Venezuela," Tree Genetics and Genomes, vol. 11, no. 3, article no. 57, 2015.

[15] A. R. Razafimahatratra, T. Ramananantoandro, V. Razafimaharo, and G. Chaix, "Provenance and progeny performances and genotype $\times$ environment interactions of Eucalyptus robusta grown in Madagascar," Tree Genetics \& Genomes, vol. 12, no. 3, p. 38, 2016.

[16] K. Ozdamar, Statistical Analysis by Package Programs, Kaan Publishing, Eskisehir, Turkey, 5th edition, 1999.

[17] A. M. Shutyaev and M. Giertych, Scots Pine (Pinus sylestris L.) in Eurasia-A Map Album of Provenance Site Interactions, Institute of Dendrology, Kornik, Poland, 2003.

[18] E. Beuker, E. Valtonen, and T. Repo, "Seasonal variation in the frost hardiness of Scots pine and Norway spruce in old provenance experiments in Finland," Forest Ecology and Management, vol. 107, no. 1-3, pp. 87-98, 1998. 
[19] R. Alía, J. Moro-Serrano, and E. Notivol, "Genetic variability of Scots pine (Pinus sylvestris) provenances in Spain: growth traits and survival," Silva Fennica, vol. 35, no. 1, pp. 27-38, 2001.

[20] J. Mikola, Provenance and Individual Variation in Climatic Hardiness of Scots Pine in Northern Finland, Plenum Press, New York, NY, USA, 1993.

[21] S. Taeger, C. Zang, M. Liesebach, V. Schneck, and A. Menzel, "Impact of climate and drought events on the growth of Scots pine (Pinus sylvestris L.) provenances," Forest Ecology and Management, vol. 307, pp. 30-42, 2013.

[22] M. P. Perks and H. M. Mckay, "Morphological and physiological differences in Scots pine seedlings of six seed origins," Forestry, vol. 70, no. 3, pp. 223-232, 1997.

[23] I. Dutkuner, N. Bilir, and M. D. Ulusan, "Influence of growth on reproductive traits and its effect on fertility and gene diversity in a clonal seed orchard of scots pine, Pinus Sylvestris L.," Journal of Environmental Biology, vol. 29, no. 3, pp. 349-352, 2008.

[24] S. Gülcü, M. Akcakaya, and N. Bilir, "Genetic variation in Anatolian black pine (Pinus nigra Arn. subsp. pallasiana (Lamb.) Holmboe.) populations," Journal of Environmental Biology, vol. 37, pp. 261-265, 2016.

[25] A. Gezer, S. Gülcü, and N. Bilir, "Provenance trials of Scots pine (Pinus silvestris L.) in Lake district region," Journal of Forestry Faculty of Suleyman Demirel University, vol. 1, pp. 1-18, 2002.

[26] A. Gezer, N. Bilir, and S. Gülcü, "Quality classification of Scots pine (Pinus silvestris L.)," in Proceedings of the 2nd Seedling Symposium, Ege University, Izmir, Turkey, September 2000. 

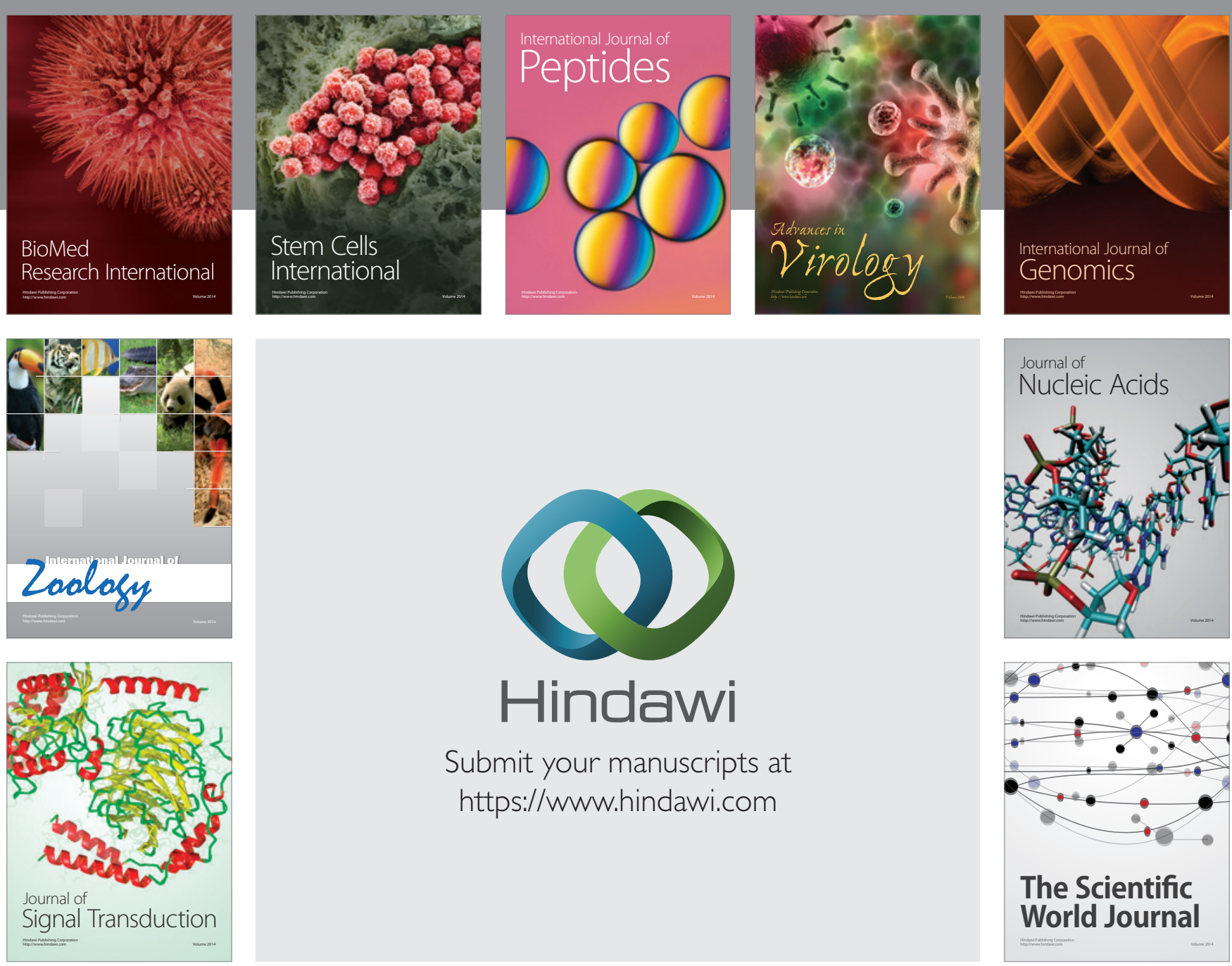

Submit your manuscripts at

https://www.hindawi.com
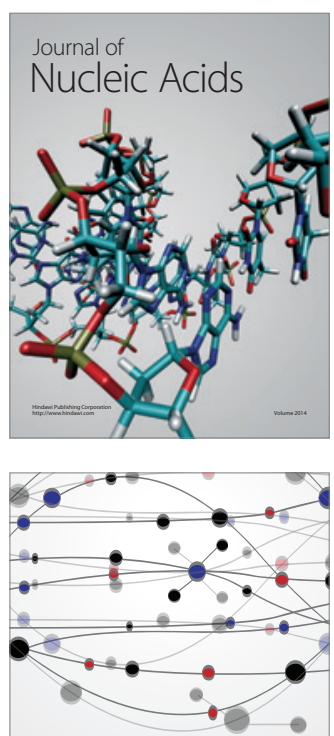

The Scientific World Journal
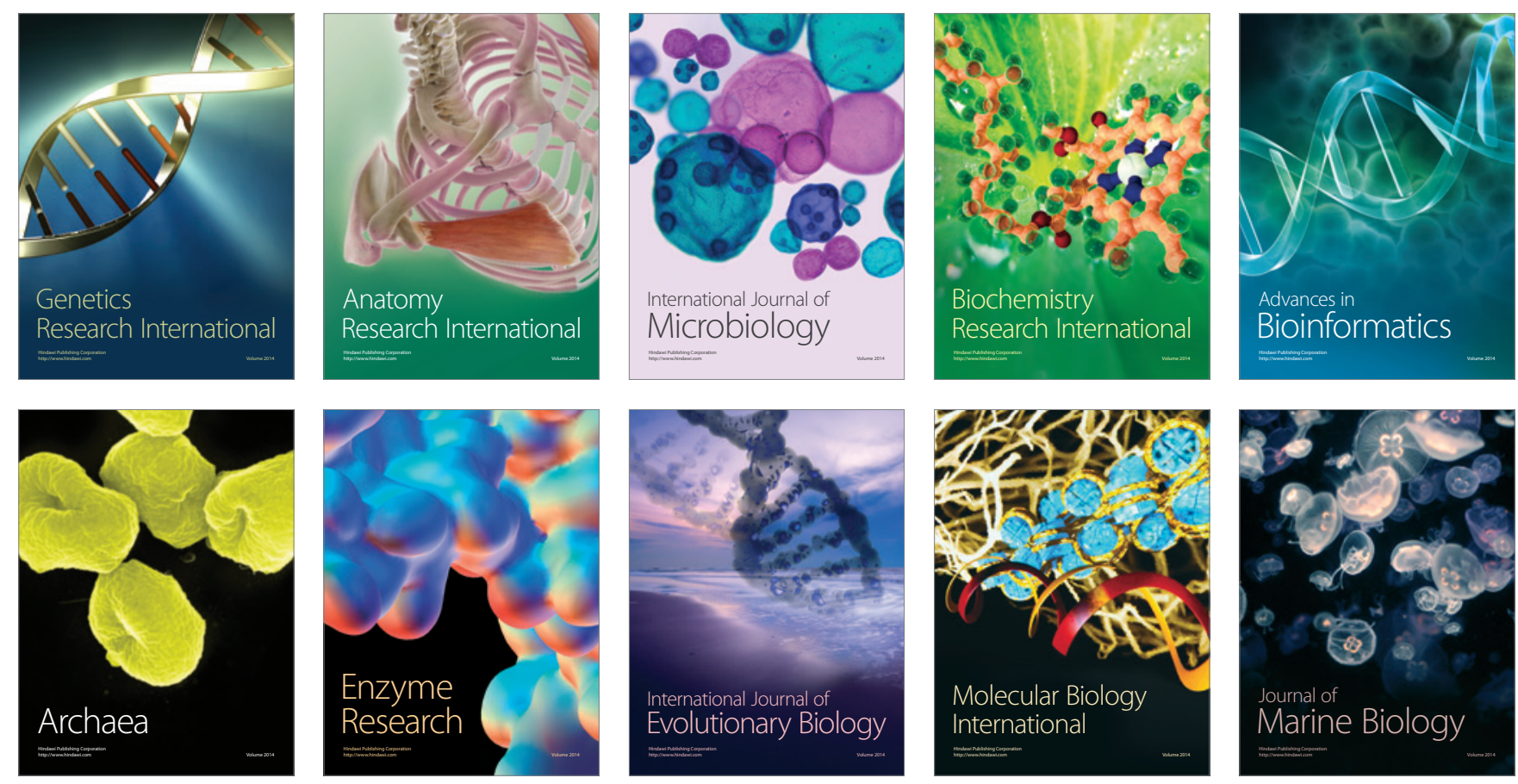